\title{
The influence of personal- and business centre characteristics on knowledge sharing types in business centres
}

\section{Citation for published version (APA):}

Weijs-Perrée, M., Appel-Meulenbroek, R., Arentze, T., \& Romme, G. (2019). The influence of personal- and business centre characteristics on knowledge sharing types in business centres. Facilities, 37(1/2), 21-37. https://doi.org/10.1108/F-07-2017-0064

DOI:

10.1108/F-07-2017-0064

Document status and date:

Published: 04/02/2019

\section{Document Version:}

Accepted manuscript including changes made at the peer-review stage

\section{Please check the document version of this publication:}

- A submitted manuscript is the version of the article upon submission and before peer-review. There can be important differences between the submitted version and the official published version of record. People interested in the research are advised to contact the author for the final version of the publication, or visit the $\mathrm{DOI}$ to the publisher's website.

- The final author version and the galley proof are versions of the publication after peer review.

- The final published version features the final layout of the paper including the volume, issue and page numbers.

Link to publication

\section{General rights}

Copyright and moral rights for the publications made accessible in the public portal are retained by the authors and/or other copyright owners and it is a condition of accessing publications that users recognise and abide by the legal requirements associated with these rights.

- Users may download and print one copy of any publication from the public portal for the purpose of private study or research.

- You may not further distribute the material or use it for any profit-making activity or commercial gain

- You may freely distribute the URL identifying the publication in the public portal.

If the publication is distributed under the terms of Article 25fa of the Dutch Copyright Act, indicated by the "Taverne" license above, please follow below link for the End User Agreement:

www.tue.nl/taverne

Take down policy

If you believe that this document breaches copyright please contact us at:

openaccess@tue.nl

providing details and we will investigate your claim. 


\title{
Sharing different types of knowledge in business centres
}

\begin{abstract}
Purpose - Knowledge sharing is a process where individuals mutually exchange knowledge to create new knowledge. Understanding the knowledge sharing process, during which organizations share spaces, facilities and services, is highly important for owners/managers who seek to optimize their business centre and to attract more innovative tenants. For users of business centres it is interesting to know how, where and what type of knowledge is shared. However, there is hardly any research into sharing different types of knowledge in business centres. The purpose of this research is to analyse the influence of personal- and organizational characteristics on sharing different types of knowledge within and between organizations in business centres.

Design/methodology/approach - Data was collected by using a questionnaire that was completed by 268 users of 53 business centres in the Netherlands. A seemingly unrelated regression analysis was used to simultaneously analyse the influence of personal and organizational characteristics on knowledge sharing in business centres.

Findings - The results show that public and private non-codified knowledge is more frequently shared with people from other organizations by those who more frequently use an event space, lounge space, canteen or consultancy services. Knowledge sharing within organizations was influenced by the use of individual closed workspaces, meeting spaces and a restaurant/canteen and gender.

Originality/value - The study suggests that owners and managers of business centres can optimize their business centre by offering specific facilities, services and workspaces to attract a specific group of tenants. In addition, organizations that want to enhance knowledge sharing with other organizations need to stimulate their employees to use shared facilities and services.
\end{abstract}

Keywords Business centre, knowledge sharing, facilities, personality, seemingly unrelated regression analysis

Paper type Research paper 


\section{Introduction}

Organizations, especially freelancers and SME's, are increasingly looking for accommodation in a business centre because of the decreasing need of workspace, the increasing need for flexibility, and an increasing need for a higher service level (e.g. Gibson, 2003; Barber et al., 2005). A business centre can be defined as a building with a number of spaces and possible some common facilities and/or services, which are offered to multiple organizations (Calder and Courtney, 1992; Weijs-Perrée et al., 2016).

One of the most important advantages of a business centre is the opportunity to share knowledge with other organizations, because knowledge is a highly important resource for organizations (e.g. Wang and Noe, 2010). Four types of knowledge can be distinguished, namely sharing public non-codified knowledge, public codified knowledge, private non-codified knowledge and private codified knowledge (Marouf, 2007). This distinction is based on the level of codification of knowledge (i.e. documented in some form) and whether it is public or private (i.e. not publicly available or guaranteed by third parties).

Non-codified knowledge appears to be critical to innovation processes in organizations (Marouf, 2007). For organizations, it is therefore important to get insight in their knowledge sharing behaviour and which factors of the physical work environment of business centres influence the sharing of different types of knowledge. Owners and managers could use such insights to create work environments that stimulate specifically private non-codified knowledge sharing between organizations and thus develop their office into an innovative hotspot.

Previous studies mainly focused on the influence of the layout of the work environment of single-tenant offices on the overall knowledge sharing behaviour within a large organization. These studies showed for example that shared facilities or spaces, open and flexible workspaces are important for facilitating knowledge sharing (e.g. Staplehurst and Ragsdell, 2010; Kastelein, 2014; Rashid et al., 2009; Appel-Meulenbroek, 2010). However, research into the influence of the physical work environment of business centres on the type of knowledge (i.e. content) that is shared between and within organizations is still scarce.

Personality and demographics are also important indicators of sharing knowledge. For example, differences were found between men and women sharing non-codified knowledge. Men discuss more often their work during an interaction than women (Pangil and Nadurdin, 2008). With regard to personality, research showed that people who are more agreeable and conscientiousness are also more willing to share knowledge (e.g. Gharanjik and Azma, 2014; Matzler et al., 2008; Gupta, 2008). However, these studies also focus on knowledge sharing within larger organizations, instead of between organizations (i.e. freelancers or SME's) at the scale of a business centre. So far, research into the relationship between personality, demographics, the physical work environment and sharing different types of knowledge within and between organizations in business centres is limited. The aim of this study is, therefore, to analyse the influence of personal- and business centre characteristics on knowledge sharing in business centres. Data was collected among 268 users of 53 business centres in the Netherlands. The data was analysed by using a seemingly unrelated regression analysis (SUR).

The following section reviews the existing literature on knowledge sharing, personal characteristics, the physical work environment and knowledge sharing. Then, the data collection and methodology are described. In the fourth section the main results are discussed. The final section contains the conclusion and discussion. 


\section{Knowledge sharing}

Knowledge is one of the most important resources of an organization (Ipe, 2003; Van den Hooff and Hendrix, 2004), especially in today's 'knowledge economy' (e.g. Yao and Fan, 2015). Knowledge sharing has therefore increasingly been receiving attention of organizational leaders. It is important that organizations not only acquire knowledge within the organization but also acquire knowledge from other organizations. Organizations could benefit and learn from each other's knowledge, which eventually could lead to creating new knowledge (Marouf, 2007).

Knowledge exists at the individual, group, department, division and organizational level (Ipe, 2003). Although knowledge is based on data and information, it cannot be considered separately from the people who create, use and change knowledge (Alipour et al., 2011). Knowledge can be described as (Alavi and Leidner, 2001, p. 109):

information possessed in the mind of individuals: it is personalized information (which may or may not be new, unique, useful, or accurate) related to facts, procedures, concepts, interpretations, ideas, observations, and judgments'

This definition has been widely used (e.g. Hansen and Avital, 2005; Chen et al., 2010; Yu et al., 2010), because it shows the importance of the role of individuals in sharing knowledge.

Several studies have tried to categorize knowledge into different forms or types. First, Polanyi's (1958) distinction between explicit and tacit knowledge is widely used in research on knowledge sharing (e.g. Nonaka et al., 2000; Seidler-de Alwis and Hartmann, 2008). This distinction is widely used in knowledge (sharing) research (e.g. Nonaka et al., 2000; Seidler-de Alwis and Hartmann, 2008). Explicit knowledge (i.e. codified) can be deposited, managed, transmitted and stored. This type of knowledge can be found in for example books, newspapers, magazines, television and Internet. It can be shared in the form of data, scientific formulas, manuals or patents. Next, tacit knowledge (non-codified) can be described as personal knowledge and arises from for example procedures, commitment, values and emotions. Tacit knowledge is, because of its personal character, difficult to formalize and communicate (Nonaka, 1994). Tacit knowledge is acquired by sharing experiences, observation or imitation (Seidler-de Alwis and Hartmann, 2008).

Knowledge can also be individual (within a person's mind) or collective (knowledge of a group of people) in nature (e.g. Kastelein, 2014). Marouf (2007) used the terms codified and non-codified, instead of explicit and tacit knowledge, and explores whether knowledge is private (not publicly available or guaranteed by third parties) or public (available and verifiable through third parties). These two dimensions serve to distinguish:

- Public non-codified knowledge: general, work-related, context-free, depersonalized, verifiable through third parties and not documented in any form;

- $\quad$ Public codified knowledge: general, work-related, context-free, depersonalized, verifiable through third parties, documented in some form and written in the form of standard instruments (e.g. company reports and manuals);

- Private non-codified knowledge: personal or informal, context-specific, subjective, personally sensitive and not documented in any form (e.g. beliefs, viewpoints, insights and experiences);

- $\quad$ Private codified knowledge: informal or personal, context-specific, personally, sensitive, and documented in some form (e.g. correspondence and personal notes). 
This typology is an extension of the widely known distinction between codified and non-codified knowledge, and thus better reflects real-world situations. For example, not all codified knowledge is available for use and not all non-codified knowledge is private (Marouf, 2007). These different forms of knowledge are simple, easy to use in models and easy to explain to people in practical life (Marouf, 2007; Mládková, 2014).

Specifically, private non-codified knowledge is important for the target groups of business centres (i.e. freelancers and SME's), where this type of knowledge is mostly shared through (informal) face-to-face interactions (Wang and Noe, 2010) and highly important for creative and innovative work (Ngah and Jusoff, 2009). In addition, it is recognized that noncodified (tacit) knowledge adds more value to the innovation process than codified knowledge (Marouf, 2007).

Knowledge sharing, which is an activity through which knowledge is exchanged, has received increasing attention (De Vries et al., 2006). For example, Easterby-Smith et al. (2008) suggested that knowledge sharing between organizations is more complex than knowledge sharing within an organization, because of more substantial boundaries between different organizational cultures and processes. However, organizations could improve their competitive advantage, knowledge and innovative capabilities by sharing knowledge across organizations (Easterby-Smith et al., 2008). Therefore, it is important to not only analyse knowledge sharing within an organization, but also between organizations and to focus on different types of knowledge that is shared.

An increasing number of studies analysed personal factors (e.g. personality, demographics and work-related characteristics) that can influence this knowledge sharing within an organization. First, personality is an important indicator of knowledge sharing (e.g. Matzler et al., 2008; Gupta, 2008). The Big Five Factor Model (extraversion, agreeableness, conscientiousness, openness and neuroticism) is a generally accepted model for describing individual personalities (Cabrera et al., 2008). Previous studies showed that people who are more agreeable and conscientious are more involved in knowledge sharing activities (Gupta, 2008) and people who are more conscientious, agreeable, open and neurotic are more willing to share knowledge (Gharanjik and Azma, 2014; Matzler et al., 2008). People who are more agreeable, extravert and open are probably also more willing to share private (non-codified) knowledge with others, which is important to be innovative.

Furthermore, several studies analysed the relationship between demographics and knowledge sharing within a (larger) organization (e.g. Ismail and Yusof, 2009; Pangil and Nadurdin, 2008). These studies did not find any relation between age, education level, work experience, organizational tenure, job tenure and knowledge sharing. However, the evidence regarding the influence of gender differences is mixed. Studies showed that female entrepreneurs have a smaller entrepreneurial network (Klyver and Grant, 2010) and less often discuss their work during an interaction (Pangil and Nadurdin, 2008). Therefore, woman probably also share less non-codified knowledge with others. On the other hand, Alhammad et al. (2009) found no significant relation between gender and knowledge sharing. Although a few relations were found between personal characteristics and knowledge sharing in previous studies, it remains unknown if personal characteristics influence knowledge sharing within and between organizations at the scale of a business centre. 


\section{Business centre characteristics}

Business centres could vary depending on the level of shared services and facilities/spaces that are offered. Several services can be described based on existing literature (e.g. Weijs-Perrée et al., 2016; Laterveer, 2011; Calder and Courtney, 1992; Ketting, 2014; Troukens, 2001), namely business services, secretarial services, cleaning and maintenance, security, managed technology, consultancy services, networking events, catering, use of coffee and tea services and furniture. The use of these services could influence the way and what type of knowledge people share within organizations and with people from other organizations in the business centre. For example, the use of networking events probably increases sharing public non-codified knowledge, as people mostly attend these events to meet new interesting people to share common and new knowledge. Consultancy services can help and provide organizations with new knowledge to improve their performance. Business centres also provide concentration rooms, office space with fixed workstations, office space with shared workstations, a combination of fixed and shared workstations, atelier space, laboratory space, conference room, informal/social space, project/creative space, reception, kitchen, coffee corner, storage room, showroom or a business unit (Weijs-Perrée et al., 2016).

Previous studies showed the importance of the physical work environment for knowledge sharing within larger organizations. For example, different office designs and workspaces are likely to influence knowledge sharing in a different way (Kastelein, 2014; Suckley and Dobson, 2014; Rashid et al., 2009). Open-plan offices stimulate the number of interactions and therefore probably knowledge sharing behaviour as well (Blakstad et al., 2009; Becker and Sims, 2001; Chigot, 2003). Although open work environments stimulate non-codified knowledge, this knowledge is more likely to be public, because for sharing more private knowledge people might want more privacy (e.g. a closed meeting space). A workstation (desk) is one of the most important knowledge sharing facilities (Staplehurst and Ragsdell, 2010), because interactions often occur in or near workstations (e.g. Rashid et al., 2009). Van der Voordt and Van Meel (2000) suggested that a non-territorial workspace (a workspace that is flexibly used by employees who do not own a workspace) could lead to problems for interactions, as people cannot find each other or a suitable workspace. Thus, if people cannot find each other, they probably share less non-codified knowledge with each other and thus relatively more codified knowledge (e.g. through e-mail). On the other hand, using a non-territorial workspace might increase the chance people interact and share knowledge with new people (e.g. people from other organizations). It is also recognized that meeting spaces (Staplehurst and Ragsdell, 2010), informal meeting spaces (Chevez and Aznavoorian, 2014), flexible individual workspaces (Binyaseen, 2010), open and common workspaces and common shared areas (e.g. kitchen, play/game rooms, lounges and library) (Kastelein, 2014) are important facilities or spaces that could increase the number of interactions and eventually sharing (non-codified) knowledge.

In summary, based on previous studies in single-tenant offices, it is assumed that personal differences (i.e. demographics and personality differences), the use of offered facilities and services (e.g. meeting spaces, informal/social spaces) as well as the workspace type may influence sharing different types of knowledge within and between organizations (see Figure 1). Previous studies have not considered the influence of the physical work environment of business centres on sharing the different types of knowledge. Especially in business centres, where organizations share spaces, facilities and services, and where knowledge sharing is an important motivation to use these offices (e.g. Sykes, 2014), further research on this topic is needed. Therefore, this study contributes to previous work by analysing existing theory on the influence 
of the physical work environment on knowledge sharing in a different context (i.e. business centres), controlling for personal characteristics in a multivariate framework. A second contribution of this study is that besides knowledge sharing behaviour within an organisation, also knowledge sharing between organizations (mostly SME's and self-employed workers) is analysed. Finally, this study focused on sharing different types of knowledge sharing, which was still missing in previous workplace research.

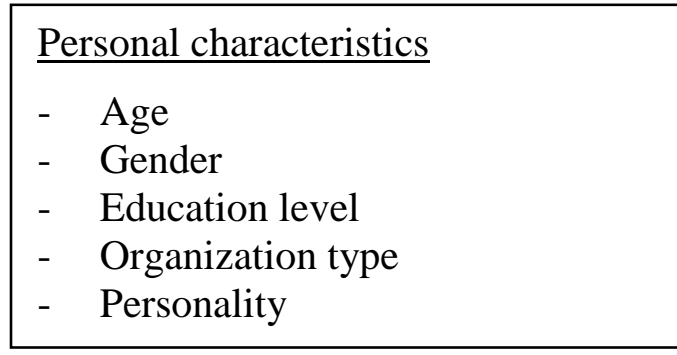

The use of shared facilities

- Kitchen

- Print/copy area

- Elevator

- Coffee corner

- Meeting space/conference room

- Restaurant/canteen

- Informal/social meeting space

- Concentration room

- Common terrace

- Lounge room

- Event space

- Project-, creative- or classroom

- Atelier space

The use of shared services

- Use of coffee/tea

- Managed technology

- Secretarial services

- Networking events

- Catering

- Furniture

- Workshops/lectures

- Business services

- Consultancy services

Workspace characteristics

- Workplace type

- Workplace use

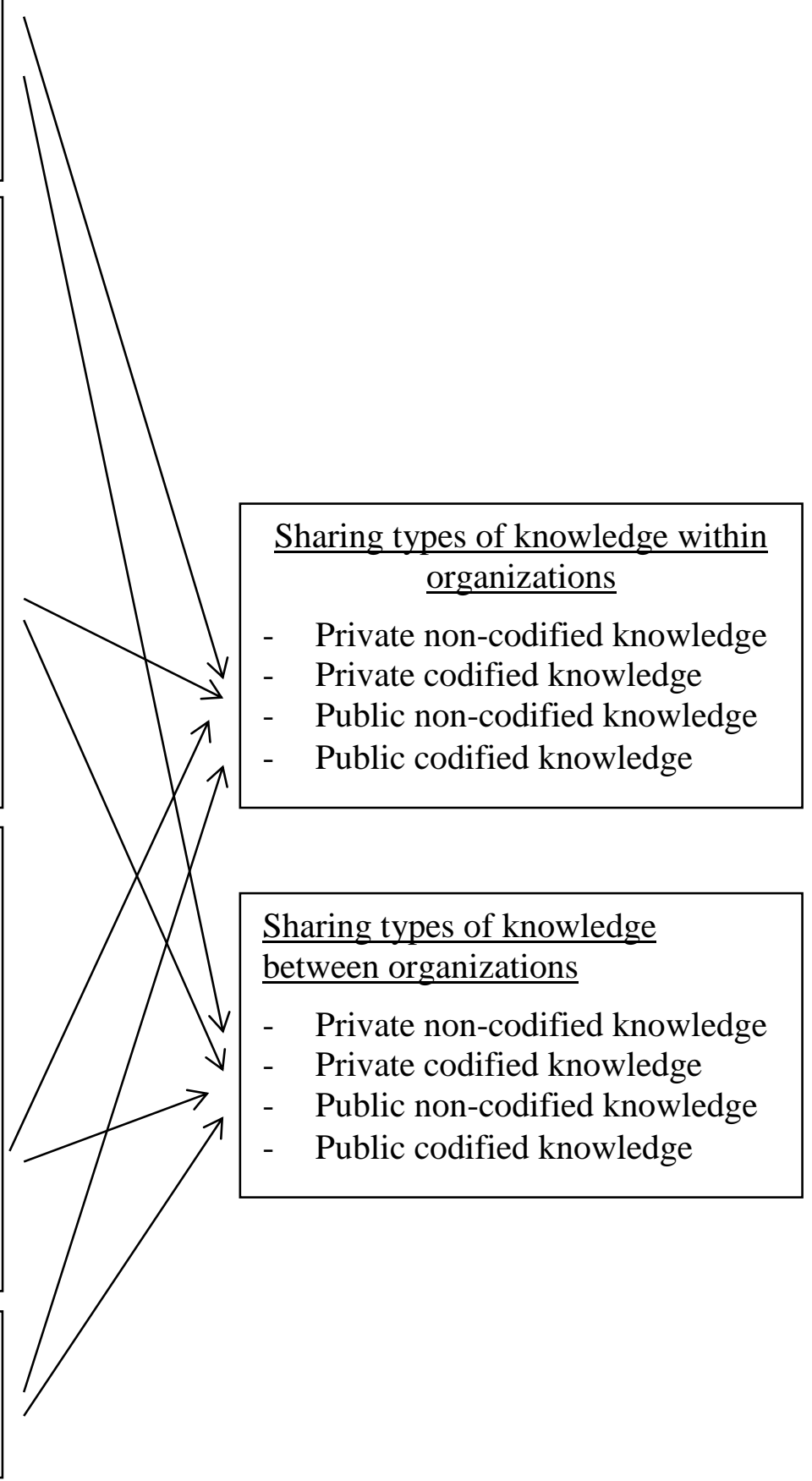




\section{Methodology}

Data was collected in January and February 2016 by means of a questionnaire. The aim of the data collection was to collect data of users of 139 business centres that participated in a previous study. Owners and managers of these business centres were asked to distribute the questionnaire among all their tenants, who were subsequently asked to distribute the questionnaire among their employees. In addition, some business centre users were personally approached to increase the response rate. This resulted in a total of 299 questionnaires (177 online and 122 paper-and-pencil questionnaires). Only 268 questionnaires were used in the final analysis, because 32 questionnaires had several missing values.

This questionnaire consists of open and multiple choice questions about the respondent's personal- and work related characteristics, namely age, gender, education level, organization type, work situation, hours working in the business centre, position in the organization and business club memberships. Respondents were also asked about their personality. Personality was measured using the Five Factor Model (extraversion, agreeableness, conscientiousness, emotional stability and openness), using the Ten-Item Personality Inventory (TIPI) (Goslin et al., 2003). Respondents were asked to indicate if they agree with ten personality traits (i.e. extraverted, enthusiastic; critical, quarrelsome; trustworthy/ disciplined; anxious, easily upset; open to new experiences, complex; reserved, quiet; sympathetic, warm; disorganized, careless; calm, emotionally stable; traditional, uncreative), ranging from (1) strongly disagree, to (7) strongly agree.

The four types of knowledge sharing were measured based on the distinction by Marouf (2007). In the questionnaire, respondents were asked about the frequency, ranging from (1) never to (7) multiple times a day, they share the four types of knowledge within organizations and people from other organizations.

With regard to the business centre characteristics, respondents were asked about their workspace type and use. Respondents could choose from the following types of workplaces namely if they work alone in a closed space, together with others in a closed space, an open space with and without partitions. In addition, they were asked about the use of their workspace (i.e. a personal office that is used by one person, a workspace that is shared by two or more fixed users and a flexibly used workspace that is freely used by all employees) (adapted from Van Meel, 2000). Furthermore, respondents could indicate the frequency that they use an offered shared facility on a 7-point Likert scale ranging from (1) never to (7) multiple times a day. If the facility was not available in the business centre, respondents reported the frequency as 0 (never). In addition, the use of services was measured by asking respondents if they use (yes/no) offered services in the business centre.

Although the frequencies of sharing the different types of knowledge are measured on a 7-point scale, these are considered as interval variables in the analyses. To simultaneously analyse the relations between different sets of personal- and business centre characteristics (independent variables) and different types of knowledge sharing (as dependent variables) in a single model system, a seemingly unrelated regression analysis (SUR) was used. A SUR is used when multiple regression equations, with different dependent variables that are related to each other and different sets of independent variables, are analysed at the same time (Sun et al., 2014). In this study, the equations with the four types of knowledge sharing as dependent variables are also related to each other. Therefore, SUR is a suitable method, as an extension of linear regression analysis that allows correlated errors between equations (Sun et al., 2014). 
First, eight multiple regression analyses (stepwise) were performed. Based on these analyses, variables that were found to have a significant effect on the dependent variables were included in the SUR analysis. Variables that were not found to have a significant effect in the multiple regression analyses were not included in the SUR (i.e. empty cells in Table 3 and 4).

\section{Sample}

Table 1 shows the sample characteristics. The sample consists of $68 \%$ men and $32 \%$ women. The average age of the respondents is 40 years, with a standard deviation of 12 . A high percentage of the respondents $(80 \%)$ have a high educational level (undergraduate or post graduate). Most respondents work as a freelancer (30\%) or work at a SME (39\%). Only a small percentage of the respondents (15\%) work at a start-up enterprise or at a large enterprise (8\%). Many respondents (40\%) work on a fulltime basis. Most respondents are extraverted, open to new experiences, sympathetic, self-disciplined and emotionally stable. With regard to knowledge sharing, respondents share weekly knowledge within organizations and less than once a month with people from other organizations. Public codified knowledge is the least shared by respondents and private knowledge is shared the most in the business centres.

Table 2 shows the descriptive statistics of the business centre characteristics. Accordingly, respondents most frequently use the kitchen, print/copy area, elevator and the coffee corner. A concentration room, common terrace, lounge space, event space, project-, creative- or classroom and atelier space, were used less frequently. These spaces are probably less frequently offered by the business centre. With regard to the services that are offered, $40 \%$ of the respondents use coffee/tea services, 37\% use managed technology services, 35\% use secretarial services and $30 \%$ of the respondents attend organized networking events. Only $3 \%$ of the respondents use business and consultancy services. These services are not always offered by the business centre. Furthermore, most respondents work together or alone in a closed office $(76 \%)$ and have a fixed workspace $(79 \%)$. Only $9 \%$ of the respondents work in a flexible workspace. 
Table 1 Descriptive statistics of personal characteristics and knowledge sharing $(\mathrm{N}=268)$

\begin{tabular}{|c|c|c|c|c|}
\hline & $\begin{array}{c}\text { Sample } \\
(\mathrm{N})\end{array}$ & $\begin{array}{c}\text { Sample } \\
(\%)\end{array}$ & Mean & St. Dev. \\
\hline Age & 267 & & 40.32 & 12.033 \\
\hline \multicolumn{5}{|l|}{ Gender } \\
\hline Male & 181 & 68 & & \\
\hline Female & 87 & 32 & & \\
\hline \multicolumn{5}{|l|}{ Gross annual Income } \\
\hline Low income $(<€ 30.000)$ & 89 & 33 & & \\
\hline Moderate income $(€ 30.000-€ 50.000)$ & 71 & 27 & & \\
\hline High income $(>€ 50.000)$ & 87 & 32 & & \\
\hline (Missing) & 21 & 8 & & \\
\hline \multicolumn{5}{|l|}{ Education level } \\
\hline Secondary or vocational education & 54 & 20 & & \\
\hline Undergraduate & 139 & 52 & & \\
\hline Postgraduate & 75 & 28 & & \\
\hline \multicolumn{5}{|l|}{ Work situation } \\
\hline Fulltime employee & 108 & 40 & & \\
\hline Part-time employee & 36 & 13 & & \\
\hline Works on a project basis or student & 30 & 11 & & \\
\hline $\begin{array}{r}\text { Not applicable } \\
\end{array}$ & 94 & 35 & & \\
\hline \multicolumn{5}{|l|}{ Organization type } \\
\hline Freelancer & 80 & 30 & & \\
\hline Small and medium-sized enterprises & 106 & 39 & & \\
\hline Start-up enterprises ( $\geq 2$ employees) & 41 & 15 & & \\
\hline Large enterprise & 21 & 8 & & \\
\hline Other & 20 & 8 & & \\
\hline \# Hours spent in the business centre & & & 32.96 & 11.966 \\
\hline \# Business club memberships & & & 1.16 & 1.436 \\
\hline \multicolumn{5}{|l|}{ Personality traits (1) strongly disagree to (7) strongly agree } \\
\hline $\begin{array}{ll}\text { Extraverted, enthusiastic } \\
\end{array}$ & & & 5.30 & 1.167 \\
\hline Critical, quarrelsome & & & 4.64 & 1.425 \\
\hline Dependable, self-disciplined & & & 5.85 & 1.145 \\
\hline Anxious, easily upset & & & 2.20 & 1.263 \\
\hline Open to new experiences, complex & & & 5.78 & 1.059 \\
\hline Reserved, quiet & & & 4.74 & 1.449 \\
\hline Sympathetic, warm & & & 5.68 & 1.059 \\
\hline Disorganized, careless & & & 2.52 & 1.420 \\
\hline Calm, emotionally stable & & & 5.37 & 1.220 \\
\hline Conventional, uncreative & & & 2.65 & 1.398 \\
\hline \multicolumn{5}{|c|}{ Knowledge sharing within the organization: (1) never to (7) multiple times a day } \\
\hline Public non-codified KS & & & 4.27 & 1.958 \\
\hline Public codified KS & & & 4.29 & 2.264 \\
\hline Private non-codified KS & & & 4.63 & 2.129 \\
\hline Private codified KS & & & 4.57 & 2.215 \\
\hline \multicolumn{5}{|c|}{ Knowledge sharing with people from other organizations: (1) never to (7) multiple times a day } \\
\hline Public non-codified KS & & & 2.10 & 1.211 \\
\hline Public codified KS & & & 1.74 & 1.167 \\
\hline Private non-codified KS & & & 2.20 & 1.355 \\
\hline Private codified KS & & & 1.99 & 1.311 \\
\hline
\end{tabular}


Table 2 Descriptive statistics of business centre characteristics $(\mathrm{N}=268)$

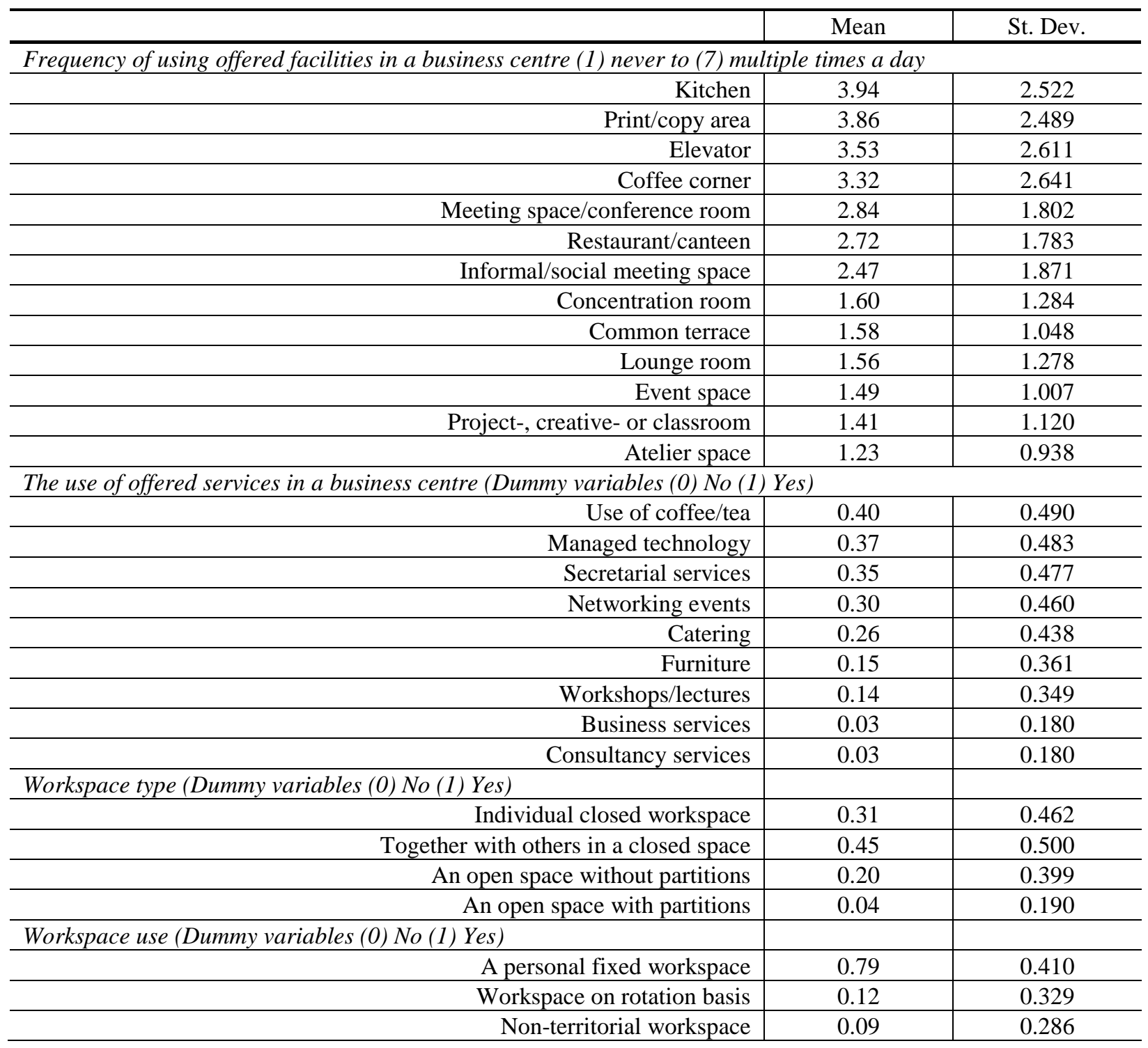

\section{Model results}

The normal probability plot of the residuals of the regression analyses shows that most of the residuals are normally distributed. Some of the residuals are slightly skewed and therefore the results should be interpreted carefully. The results of the SUR (see Table 3 and 4) indicate that sharing the four types of knowledge is indeed influenced by personal characteristics, the frequency of using offered facilities/services and workspace characteristics. The regression sum of squares (SSR) measures how much of the total variation is explained by the regression. In addition, the mean square error (MSE) measures the fit to the data. The smaller the MSE, the better the model explains the data (Li, 2010).

The first model (i.e. knowledge sharing within organizations) has an adjusted $\mathrm{R}^{2}$ of 0.307 for explaining the public non-codified knowledge, 0.332 for explaining public codified 
knowledge, 0.382 for explaining private non-codified knowledge and 0.337 for explaining private codified knowledge. Overall, the personal- and business centre characteristics explain between $33.2 \%$ and $38.2 \%$ of the total variance of the types of knowledge sharing. In the second model (i.e. knowledge sharing between organizations), personal- and business centre characteristics explain between $18.6 \%$ and $31.2 \%$ of the total variance of the types of knowledge sharing. Thus, probably other characteristics are important for explaining knowledge sharing between organizations than for sharing different types of knowledge within an organization. For example, differences in organizational culture (Xerri and Brunetto, 2010), structure (Chen and Huang, 2007) and size (Chevez and Aznavoorian, 2014) could also influence knowledge sharing between organizations.

\section{Knowledge sharing within organizations}

The results show that the four types of knowledge sharing are all positively influenced by younger and male workers. Although it is recognized that older employees have more valuable knowledge and work experience to share (Oye et al., 2013), results showed that older employees share less frequently knowledge within their own organization.

With regard to the physical work environment, the results show that frequently using a canteen (positive, except sharing public codified knowledge) and meeting space, and not having an individual closed workspace positively influence all types of knowledge sharing. Kastelein (2014) also showed that open and common workspaces, common shared areas (e.g. canteen or lounge space) and meeting spaces are the most important facilities for enabling interactions between colleagues. In addition, meeting rooms appear to be one of the most important knowledge sharing facilities for SME's (Staplehurst and Ragsdell, 2010).

Table 3 shows that more private non-codified knowledge is shared by people who more frequently use a space for copying and printing. It was known that an area for printing and copying stimulates unplanned encounters, for example when people are waiting for printouts (Hua et al., 2010). The results add to this previous work that also the particularly important private non-codified knowledge (Marouf, 2007) is more frequently shared in printing/copying areas. The results also show that frequently using a project/classroom negatively influences the frequency of sharing public non-codified knowledge within organizations. These spaces are probably used for team meetings where privacy is necessary and thus more private non-codified knowledge is shared. However, no significant relation was found between sharing private knowledge and the use of a project- or class room. Furthermore, knowledge sharing within organizations is not influenced by one of the personality traits. Typical business centre facilities/services (e.g. lounge space, event space and consultancy services) were also not found to have a significant effect on knowledge sharing within organizations. 
Table 3 Results for knowledge sharing (KS) within organizations

\begin{tabular}{|c|c|c|c|c|}
\hline & $\begin{array}{l}\text { Public non- } \\
\text { codified KS }\end{array}$ & $\begin{array}{l}\text { Public codified } \\
\text { KS }\end{array}$ & $\begin{array}{l}\text { Private non- } \\
\text { codified KS }\end{array}$ & $\begin{array}{l}\text { Private codified } \\
\text { KS }\end{array}$ \\
\hline & Coeff. & Coeff. & Coeff. & Coeff. \\
\hline \multicolumn{5}{|l|}{ Personal characteristics } \\
\hline Age & $-0.042 * *$ & $-0.046 * *$ & $-0.049 * *$ & $-0.037 * *$ \\
\hline Male & $0.697 * *$ & $1.147 * *$ & $1.055 * *$ & $1.111 * *$ \\
\hline Low education & & & & $-0.452 * *$ \\
\hline \multicolumn{5}{|l|}{ Hours working } \\
\hline Start-up enterprise & -0.230 & 0.012 & & -0.423 \\
\hline \multirow{2}{*}{\multicolumn{5}{|c|}{$\begin{array}{l}\text { Club membership } \\
\text { Personality traits }\end{array}$}} \\
\hline & & & & \\
\hline \multicolumn{5}{|l|}{ Traditional/uncreative } \\
\hline \multicolumn{5}{|l|}{ Trustworthy/disciplined } \\
\hline Sympathetic/warm & & 0.069 & 0.096 & \\
\hline \multicolumn{5}{|c|}{ Frequency of using an offered shared facility/service } \\
\hline \multicolumn{5}{|l|}{ Lounge space } \\
\hline \multicolumn{5}{|l|}{ Event space } \\
\hline Canteen/restaurant & $0.144 *$ & 0.117 & $0.167 *$ & $0.163 *$ \\
\hline Space for copying and printing & & & $0.072 *$ & \\
\hline Meeting space & $0.300 * *$ & $0.326^{* *}$ & $0.324 * *$ & $0.338^{* *}$ \\
\hline Project- or class room & $-0.206 * *$ & -0.146 & & \\
\hline \multicolumn{5}{|l|}{ Consultancy services } \\
\hline \multicolumn{5}{|l|}{ Workspace characteristics } \\
\hline \multicolumn{5}{|l|}{ Non-territorial workspace } \\
\hline Individual closed workspace & $-1.728 * *$ & $-2.042 * *$ & $-1.814 * *$ & $-1.961 * *$ \\
\hline $\mathrm{R}^{2}$ & 0.325 & 0.352 & 0.398 & 0.354 \\
\hline Adjusted $\mathrm{R}^{2}$ & 0.307 & 0.332 & 0.381 & 0.337 \\
\hline SSR (Regression Sum of Squares) & 1034.948 & 1277.800 & 1063.315 & 1236.689 \\
\hline MSE (Mean Square Error) & 3.980 & 4.936 & 4.090 & 4.757 \\
\hline
\end{tabular}

$*$ and $* *$ indicate that the coefficient is significant at the 0.05 and 0.01 level

\section{Knowledge sharing between organizations}

As can be inferred from Table 4, freelancers share more public non-codified knowledge with people from other organizations than other user groups in the business centre. Club membership increases the frequency of sharing private non-codified knowledge. With regard to personality, traditional or uncreative people less frequently share private non-codified knowledge with people from other organizations (e.g. beliefs, viewpoints, insights, and experiences). Previous studies also showed that people who are more open to new experiences are more willing to share knowledge (Matzler et al., 2008; Gharanjik and Azma, 2014). However, previous studies did not look into the influence of personality of business centre users on sharing different types of knowledge. Furthermore, results show that personal characteristics, such as age and gender are less important for knowledge sharing between organizations, compared to knowledge sharing within organizations.

With regard to shared facilities/services, the results show that the frequency of using a lounge space and canteen/restaurant increases the frequency of sharing all four types of knowledge with people from other organizations. In addition, people using an event space more often share public non-codified and private knowledge more frequently with people from other organizations. It was known that common areas in single-tenant offices stimulate interactions 
between people (Kastelein, 2014). These results contribute to existing literature that using shared informal facilities and services in business centres could stimulate sharing non-codified knowledge between organizations as well, which is important for the innovative capabilities of organizations (Marouf, 2007). Although printing/copying areas were found to be important facilities for sharing private non-codified knowledge within organizations, no significant effects were found for knowledge sharing between organizations. Conversations at a printing/copying facility might be too short and casual to share knowledge between organizations.

Private and public codified knowledge is more frequently shared by people who use a non-territorial workspace that is used by all business centre users. A previous study in singletenant offices showed that interactions often occur in or near workstations (e.g. Rashid et al., 2009). Therefore, the use of workspaces in business centres is also very important for knowledge sharing with people from other organizations, especially with regard to codified knowledge. This shows the strength of implementing non-territorial workspaces (mostly available in co-working spaces) for creating a knowledge sharing community.

Table 4 Results for knowledge sharing (KS) between organizations

\begin{tabular}{|c|c|c|c|c|}
\hline & $\begin{array}{l}\text { Public non- } \\
\text { codified KS }\end{array}$ & $\begin{array}{l}\text { Public codified } \\
\text { KS }\end{array}$ & $\begin{array}{l}\text { Private non- } \\
\text { codified KS }\end{array}$ & $\begin{array}{l}\text { Private codified } \\
\mathrm{KS}\end{array}$ \\
\hline & Coeff. & Coeff. & Coeff. & Coeff. \\
\hline \multicolumn{5}{|l|}{ Personal characteristics } \\
\hline \multicolumn{5}{|l|}{ ב } \\
\hline Male & & 0.126 & & \\
\hline \multicolumn{5}{|l|}{ Low education } \\
\hline Hours working & & & & 0.004 \\
\hline Freelancer & $0.234 *$ & & & \\
\hline \multicolumn{5}{|l|}{ Start-up enterprise } \\
\hline Club membership & 0.054 & & $0.102 *$ & 0.054 \\
\hline \multicolumn{5}{|l|}{ Personality } \\
\hline Traditional/ uncreative & & & $-0.083 * *$ & \\
\hline Trustworthy/ disciplined & 0.0619 & & & \\
\hline \multicolumn{5}{|l|}{ Sympathetic/ warm } \\
\hline \multicolumn{5}{|c|}{ Frequency of using an offered shared facility/service } \\
\hline Lounge space & $0.266^{* * *}$ & $0.285 * *$ & $0.307 * *$ & $0.339 * *$ \\
\hline Event space & $0.150^{*}$ & & $0.138^{*}$ & $0.168 * *$ \\
\hline Canteen/restaurant & $0.088^{*}$ & $0.093^{*}$ & $0.116^{* *}$ & $0.094 * *$ \\
\hline Space for copying and printing & & 0.021 & & \\
\hline \multicolumn{5}{|l|}{ Meeting space } \\
\hline \multicolumn{5}{|l|}{ Project- or class room } \\
\hline Consultancy services & $1.098^{* *}$ & & 0.301 & \\
\hline \multicolumn{5}{|l|}{ Workspace characteristics } \\
\hline Non-territorial workspace & & 0.313 & & $0.458 * *$ \\
\hline \multicolumn{5}{|l|}{ Individual closed workspace } \\
\hline ( & 0.283 & 0.201 & 0.269 & 0.312 \\
\hline Adjusted $\mathrm{R}^{2}$ & 0.264 & 0.186 & 0.253 & 0.312 \\
\hline SSR (Regression Sum of Squares) & 280.592 & 290.514 & 358.369 & 315.853 \\
\hline MSE (Mean Square Error) & 1.079 & 1.109 & 1.373 & 1.210 \\
\hline
\end{tabular}




\section{Conclusion and discussion}

Business centres (especially co-working spaces and incubators) are mostly branded as innovative work environments and also valued by tenants because of knowledge sharing opportunities with other organizations. However, it was still not clear which type of knowledge users mostly share within their organization and with other organizations and how this behaviour is influenced by the physical work environment of business centres (controlling for personal characteristics). The aim of this study was therefore to analyse all hypothesized effects, based on the literature review, on sharing different types of knowledge within a business centre. It provided new insights in particularly which types of knowledge shared are influenced in which way by the physical work environment of business centres. Another contribution to previous studies is that this study looks at knowledge sharing within as well as between organizations. This study was thus able to test existing theory on knowledge sharing within organizations in a different (shared) office context and simultaneously create new theory on how to support knowledge sharing between organizations in such offices.

Results showed that personal characteristics, the use of shared facilities and services and workspace characteristics influence sharing the four different types of knowledge within and between organizations. With regard to knowledge sharing within an organization, only a few differences between the different types of knowledge were found. Sharing knowledge within organizations was influenced by the frequency of using an individual closed workspace (negatively), meeting space (positively) and a restaurant/canteen (positively). Thus, similarly as in single-tenant offices, use of these informal spaces and working in a more open and flexible workspace is also important for knowledge sharing within organizations when working in a business centre. In addition, people who are more willing to share knowledge, tend to use these spaces more frequently. Furthermore, the results showed that age and gender are important indicators for sharing all types of knowledge within organizations. HR managers of tenant organizations could stimulate older workers to share their valuable experiences and knowledge (Oye et al., 2013) with younger colleagues and vice versa, which could be beneficial for organizations.

Besides knowledge sharing within organizations, the study also analysed knowledge sharing between organizations, at the scale of a business centre which is its main contribution to existing literature. Research on knowledge sharing between organizations at the scale of a business centre is still scarce. The results showed that frequently using an informal meeting space (i.e. lounge space, event space and canteen) is important for sharing non-codified knowledge with people from other organizations. Especially, this type of knowledge is an important resource for organizations to increase their creativity and innovative capabilities (Marouf, 2007). Thus, owners or managers of business centres that aim at stimulating knowledge sharing between the tenant organizations in their buildings should offer more and attractive informal/social spaces and flexible/open work spaces. Managers of the tenant organizations should also motivate their employees to use informal/social spaces, meeting spaces and project spaces, to increase knowledge sharing within organizations and people from other organizations. For larger organizations, it is important to discuss with their facility managers to optimize the use of these meeting spaces, where smaller organizations need to discuss this matter with the building managers.

Public non-codified knowledge is more frequently shared by people who use consultancy services. No other relations were found with regard to services. This suggests that physical characteristics are more important for knowledge sharing with people from other organizations, 
than non-physical characteristics (i.e. offered services) of business centres. In addition, these services will probably be used and offered less often than spaces and facilities. Therefore, owners and managers of business centres should focus more on the physical aspects of the building to attract innovative tenants that focus on knowledge sharing. However, it is still important that business centres offer a high service level (i.e. coffee/tea facilities, catering, managed technology services and secretarial services) to differentiate themselves from other business centres and thus retain and attract more tenants.

Overall, the results provide new insights in the influence of the physical work environment of business centres on sharing types of knowledge within and between organizations. In addition, results show that knowledge sharing can also be explained by personal characteristics. These results are interesting for building managers to focus on and support tenants that want to share knowledge and to be innovative. For example, building managers could select innovative tenants, organize meetings between tenants that could learn from each other and organize networking events. They could also monitor the perceived support for knowledge sharing of tenants and adapt the physical work environment to these outcomes.

The generalizability of the results can be improved in future work by drawing on a larger dataset by analysing real-time knowledge sharing behaviour in business centres. Also, data from different countries could give more insight into cultural differences with regard to knowledge sharing.

In this study, only people's overall subjective knowledge sharing behaviour was taken into account. It is therefore interesting for future research to analyse people's preferred locations in the building to share different types of knowledge. In addition, analysing people's real-time knowledge sharing behaviour could give more insight into how, where and what type of knowledge people share in business centres.

Further research is needed on this topic and needs to include several other important knowledge sharing antecedents (e.g. network size, organizational culture, business sector and trust between people) to strengthen the analyses. It would also be interesting to analyse the influence of personal characteristics on knowledge sharing and the mediating effect of the use of space. This would give more insight in different user groups of business centres and their knowledge sharing behaviour. 


\section{References}

Alavi, M. and Leidner, D. (2001), "Knowledge Management and Knowledge Management Systems: Conceptual Foundation and an Agenda for Research", MIS Quarterly, 25, 1, 100-110.

Alhammad, L.S., Al Faori, S. and Hussan, L.S.A. (2009), "Knowledge Sharing In The Jordanian Universities", Journal of Knowledge Management Practice, 10, 3.

Alipour, F., Idris, K. and Karimi, R. (2011), "Knowledge Creation and Transfer: Role of Learning Organization”, International Journal of Business Administration, 2, 3, 61-67.

Appel-Meulenbroek, H.A.J.A. (2010), "Knowledge sharing through co-presence: added value of facilities”, Facilities, 28, 4, 189-205.

Barber, C., Laing, A. and Simeone, M. (2005), "Global workplacee trends: A North American and European comparison”, Journal of Corporate Real Estate, 7, 3, 210-221.

Becker, F. and Sims, W. (2001), "Offices that work; Balancing communication, flexibility and costs”, Ithaca, NY: International Workplace Studies Program, Cornell University.

Binyaseen, A.M.A. (2010), “Office layouts and employee participation”, Facilities, 28 (7/8), 348-357.

Blakstad, S.H., Hatling, M. and Bygdås, A.L. (2009), "The knowledge workplace - searching for data on use of open plan offices", in proceedings EFMC 2009 research symposium, 16-17 June, Amsterdam, the Netherlands.

Borgatti, S.P. and Halgin, D.S. (2011), "On network theory”, Organization Science, 22, 11681181.

Cabrera, A., Collins, W. C., and Salgado, J. F. (2006), "Determinants of individual engagement in knowledge sharing", The International Journal of Human Resource Management, 17, 2, 245264.

Calder, M. and Courtney, S. (1992), "Business centres: the UK picture", Property Management, $1,2,106-117$.

Chen, C.J. and Huang, J.W. (2007), "How organizational climate and structure affect knowledge management: The social interaction perspective", International Journal of Information Management, 27, 104-118.

Chen, C.J., Huang, J.W. and Hsiao, Y.C. (2010), "Knowledge management and innovativeness: the role of organizational climate and structure", International Journal of Manpower, 31, 8, 848870 . 
Chevez, A. and Aznavoorian, L. (2014), "Space as a knowledge management tool”, Work \& Place, 3, 2, 11-14.

Chigot, P. (2003), "Controlled transparency in workplace design: Balancing visual and acoustic interaction in office environments", Journal of Facilities Management, 2, 2, 121-130.

De Vries, R.E., Van den Hooff, B. and De Ridder, J.A. (2006), "Explaining knowledge sharing: the role of team communication styles, job satisfaction, and performance beliefs", Communication Research, 33, 2, 115-135.

Easterby-Smith, M., Lyles, M.A. and Tsang, E.W.K. (2008), "Inter-organizational knowledge transfer: Current themes and future prospects", Journal of Management Studies, 45, 4, 677-690.

Gharanjik, E. and Azma, F. (2014), "The relationship between five-factor personality and willingness of employees to share organizational knowledge", Advanced Research in Economic and Management Sciences, 17.

Gibson, V.A. (2003), “Flexible working needs flexible space?", Journal of Property Investment \& Finance, 21, 1, 12-22.

Goslin, S.D., Rentfrow, P.J. and Swann, W.B.Jr. (2003), "A very brief measure of the Big-Five personality domains", Journal of Research in Personality, 37, 504-528.

Gupta, B. (2008), "Role of personality in knowledge sharing and knowledge acquisition behaviour", Journal of the Indian Academy of Applied Psychology, 34, 1, 143-149.

Hansen, S. and Avital, M. (2005), "Share and Share Alike: The Social and Technological Influences on Knowledge Sharing Behavior", Sprouts: Working Papers on Information Environments, Systems and Organizations, 5, 1-19.

Hua, Y., Loftness, V., Kraut, R. and Powell, K.M. (2010), "Workplace collaborative space layout typology and occupant perception of collaboration environment", Environment and Planning B: Planning and Design, 37, 429-448.

Ipe, M. (2003), "Knowledge Sharing in : A Conceptual Framework", Human Resource Development Review, 2, 337-359.

Ismail, M. B., and Yusof, Z. M. (2009), "Demographic factors and knowledge sharing quality among Malaysian government officers", In Innovation and Knowledge Management in Twin Track Economies Challenges and Solutions - Proceedings of the 11th International Business Information Management Association Conference, IBIMA 2009 (Vol. 1-3, pp. 790-796). International Business Information Management Association, IBIMA.

Kastelein, J.P. (2014), “Space meets knowledge”, Doctoral dissertation, Nijenrode Business School, The Netherlands. 
Ketting, J. (2014), "Het bedrijfsverzamelgebouw. Een onderzoek naar de toegevoegde waarde van bedrijfsverzamelgebouwen", Master thesis, Delft University of Technology, faculty of Architecture and the Built Environment.

Klyver, K. and Grant, S. (2010), "Gender differences in entrepreneurial networking and participation”, International Journal of Gender and Entrepreneurship, 2, 3, 213-227.

Laterveer, M. (2011), "Serviced offices: een dynamische markt in opkomst", Master thesis, University of Utrecht.

Li, Y. (2010),'Root Mean Square Error”, in: N. J. Salkind (eds), Encyclopedia of Research Design, Volume 1. SAGE Publications, Inc., pp. 1287-1288.

Marouf, L.N. (2007), "Social networks and knowledge sharing in organizations: a case study", Journal of Knowledge Management, 11, 6, 110-125.

Matzler, K., Renzl, B., Muller, J., Herting, S., and Mooradian, T.A. (2008), "Personality traits and knowledge sharing”, Journal of Economic Psychology, 29, 301-311.

Mládková, L. (2014), "Impact of personality of knowledge worker on his work with knowledge", International Conference on Trends in Multidisciplinary Business and Economic Research, Bangkok, Thailand.

Ngah, R. and Jusoff, K. (2009), “Tacit Knowledge Sharing and SMEs' Organizational Performance", International Journal of Economics and Finance, 1, 1, 216-220.

Nonaka, I. (1994), "A dynamic theory of organizational knowledge creation”, Organization Science, 5, 1, 14-37.

Nonaka, I., Toyama, R. and Konno, N. (2000), "SECI, ba and leadership: a unified model of dynamic knowledge creation”, Long Range Planning, 33, 4-34.

Oye, N.D., Salleh, M. and Noorminshah, A. (2011), "Knowledge sharing in workplace: motivators and demotivators", International Journal of Managing Information Technology, 3, 4, 71-84.

Pangil, F. and Nadurdin, A.M. (2008), "Demographic factors and knowledge sharing behavior among R\&D Employees", Knowledge Management International Conference, Langkawi, 128133.

Polanyi, M. (1958), “Personal Knowledge: Towards a Post-Critical Philosophy”, University of Chicago Press, Chicago.

Rashid, M., Wineman, J. and Zimring, C. (2009), "Space, behavior, and environmental perception in open-plan offices: a prospective study", Environment and Planning B: Planning and Design, 36, 3, 432-449.

Seidler-de Alwis, R. and Hartmann, E. (2008), "The use of tacit knowledge within 
innovative companies: knowledge management in innovative enterprises", Journal of Knowledge Management, 12, 1, 133-147.

Staplehurst, J. and Ragsdell, G. (2010), "Knowledge Sharing in SMEs: A Comparison of Two Case Study Organizations", Journal of Knowledge Management Practice, 11, 1.

Suckley, L. and Dobson, S. (2014), "Measuring Social and Spatial Relations in an Office Move", Social Informatics, Lecture Notes in Computer Science, 8851, 487-492.

Sun, Y., Ke, R. and Tian, Y. (2014), "Some overall properties of seemingly unrelated regression models", AStA Advances in Statistical Analysis, 98, 2, 103-120.

Sykes, K. (2014), “Coworking: a workplace paradigm shift”, Contract, 55, 6, 140-145.

Troukens, F. (2001), "Demand for Serviced Office Space”, Master Thesis, Erasmus UniversityHorteco, Belgium.

Van den Hooff, B. and Hendrix, L. (2004), "Eagerness and willingness to share: the relevance of different attitudes towards knowledge sharing", Paper presented at the Fifth European Conference on Organizational Knowledge, Learning and Capabilities, Innsbruck, Austria.

Van der Voordt, D.J.M. and Van Meel, J.J. (2000), “Lessons from innovations”, in: G. Dewulf, P. Krumm, H. de Jonge (eds), Successful corporate real estate strategies. Arko Publis-hers, Nieuwegein, pp. 51-64.

Wang, S. and Noe, R.A. (2010), "Knowledge sharing: A review and directions for future research", Human Resource Management Review, 20, 115-131.

Weijs-Perrée, M., Appel-Meulenbroek, H.A.J.A., De Vries, B. and Romme, S. (2016), "Differences between business center concepts in The Netherlands", Property Management, 34, $2,100-119$.

Xerri, M. and Brunetto, Y. (2010), "The strength of workplace social network ties in SME's: a social exchange perspective", Paper presented at to Management research in a changing climate: British Academy of Management Conference, Sheffield, UK, 14-16 September.

Yao, J. and Fan, L. (2015), “The Performance of Knowledge Workers Based on Behavioral Perspective", Journal of Human Resource and Sustainability Studies, 3, 2127.

Yu, T.K., Lu, L.C. and Liu, T.F. (2010), "Exploring factors that influence knowledge sharing behaviour via weblogs", Computers in Human Behavior, 26, 32-41. 